\title{
GCU
}

Glasgow Caledonian

University

University for the Common Good

\section{Why is the future ready for environmental geotechnics?}

Mickovski, Slobodan B.

Published in:

Environmental Geotechnics

DOI:

10.1680/envgeo.13.00107

Publication date:

2016

Document Version

Author accepted manuscript

Link to publication in ResearchOnline

Citation for published version (Harvard):

Mickovski, SB 2016, 'Why is the future ready for environmental geotechnics?', Environmental Geotechnics, vol. 3, no. 2, pp. 63-64. https://doi.org/10.1680/envgeo.13.00107

\section{General rights}

Copyright and moral rights for the publications made accessible in the public portal are retained by the authors and/or other copyright owners and it is a condition of accessing publications that users recognise and abide by the legal requirements associated with these rights.

Take down policy

If you believe that this document breaches copyright please view our takedown policy at https://edshare.gcu.ac.uk/id/eprint/5179 for details of how to contact us. 
1 Why is the future ready for environmental geotechnics?

2

$3 \quad{ }^{1}$ Civil Engineering Department, School of Engineering and Built Environment, Glasgow Caledonian

4 University. Cowcaddens Rd, Glasgow G4 OBA. Tel: ++44 141 2731105. E-mail:

$5 \quad$ Slobodan.Mickovski@gcu.ac.uk

6

Keywords: bio-geotechnics, climate change, eco-engineering, geohazards mitigation, ground improvement, sustainable development,

Working in and with the construction industry in the UK as a geotechnical engineer in the past 10 years I had a chance to encounter a range of geotechnical problems and had the privilege to work on projects of varying scale each having its own peculiarities and significance. The problems each geotechnical engineer faces could roughly be classified in one or more of the following categories (Whitlow, 2000):

- Excavation and transportation of soils

- (Self-)Support of soil

- Flow of water into and within the soil

- Problems with shear strength of soil

- Problems with compressibility of soil

- Building with soils

- Contamination of soils

The challenge for me as a geotechnical engineer was to focus on the balance of the engineering solutions for the problem with the ground environment due not only to pressure from the clients and regulators but also to my increasing curiosity about the environment around the geotechnical solutions. I had to develop skills and knowledge to be aware and effectively consider the multiple layers of the environment affected by the geotechnical design and construction. Together with the traditional concerns over soil and geology, water and groundwater, financial aspects of the design and construction, the focus become shared with societal impacts, ecology, aesthetics, air quality, noise and vibration, energy and radiation, traffic and transportation, as well as preserving historical and archaeological treasures. Relatively early in my career I understood that only considering the above factors together can ensure a sustainable solution is reached - a solution which provides a balance in terms of the environment, society and financial aspects of the project. The balance is provided by the reliability, stability, durability of the solution from an engineering perspective but also its sustainability in terms of preserving and enhancing organic life, biodiversity, waste minimisation, resource preservation, etc.

This approach was adopted by many of our colleagues and not only put geotechnics in the heart of the sustainable development (Figure 1) but also gave rise to Environmental Geotechnics (EG), a subject area of civil engineering that deals with the phenomena in the interface between the nature and the man-made world. Civil and geotechnical engineers that had a chance to delve into this area on their continuous professional development paths and learned that EG provides a context where 

further.

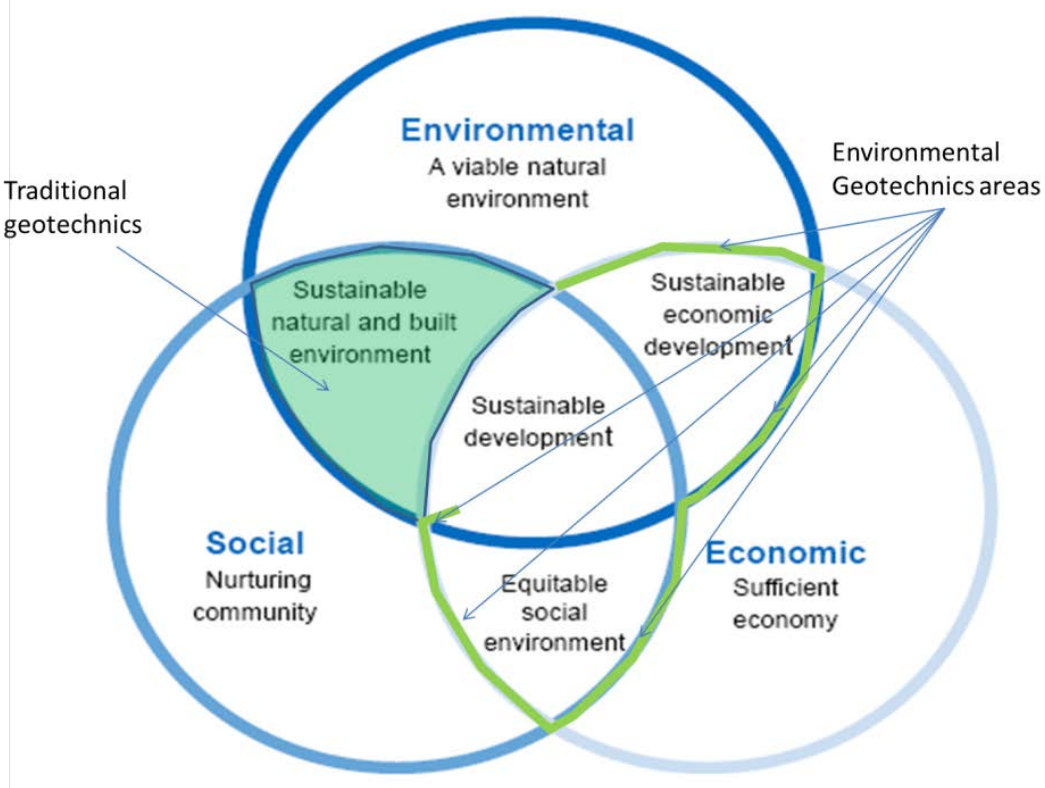

Figure 1. Traditional and environmental geotechnics in relation to sustainable development. Adapted from United Nations, 1987.

Modern geotechnical engineers, who in the past would have considered the phenomena occurring in the (primarily soil) environment, today are faced with real development in environmental sciences which become more and more detailed and sophisticated with the natural phenomena and processes surrounding civil engineering infrastructure being modelled, monitored and assessed in a more scientific way. Planners and clients often specify environmental geotechnical performance of newbuilt projects but it is the duty of the geotechnical engineer to establish and justify the design with appropriate models, calculations based on assumptions and fact (ground investigations and soil mechanics principles).

The above concerns are usually taken into account during the option selection or analysis of alternatives where the technical feasibility based on geotechnical site characterisation and design principles should be juxtaposed against the environmental and societal concerns and the geotechnical engineer is faced with the following choice of solutions:

- No action

- Avoid site

- Design around the geo-environmental constraints

While I have found that a well-established 'no action' analysis can convince the client/public of the necessity of change, and the avoidance of the site can mean either total protection or 'passing the buck' to the next developer, the real challenges lie in the last solution in the list. The geotechnical engineer is faced with a choice of either introducing imported material to site which means exploitation of extra resources, environmental concerns with transport and production of the new material, etc. or mechanically/hydraulically/physically/chemically modifying the existing site 
environment for a certain time period. Only by understanding and applying the environmental geotechnics principles can the choice be made to suit both geotechnical and environmental purposes.

In the past decade we witnessed the development and application of new plant/machinery and methods that came as a response to the environmental concerns of geotechnical engineers. Sonic drilling, intelligent compaction, geophysical methods have been developed to minimise the impact of geotechnical operations on the environment. New materials such as different polymers, fibres, foams, that provide sufficient strength while having standardised water retention properties, suitable durability, and are non-hazardous to the environment are constantly being developed. Reuse and re-cycling of waste materials such as pulverised fuel ash (PFA), crushed glass, construction rubble, used car tyres, is stipulated in the codes of practice and legislation often championed by the construction research bodies such as the Construction Industry Research and Information Association (CIRIA) , the Building Research Establishment (BRE), the Transport Research Laboratory (TRL). Through the International Conference on Soil Bio- and Eco-engineering, the International Network of ground bio- and eco-engineers (www.inbe.cirad.fr) and the World Association for Soil and Water Conservation (www.waswac.org) promote geotechnical design with vegetation not only for erosion protection but also for slope stability and remediation based on a body of international research spanning engineering and biology (Norris et al. 2008). Similarly, the latest advances in the use of micro-organisms and chemical agents for soil stability which connects geotechnics with a number of natural and physical sciences serving the environment have been recently promoted through a "Bio- and Chemo- Mechanical processes in geotechnical engineering" symposium by the Institution of Civil Engineering (ICE).

Working with geotechnics graduates and young engineers I could see the change in attitude and scope the educational institutions instilled in recent years. The development of undergraduate and postgraduate courses such as Environmental Geotechnics and Environmental Civil Engineers contributed to shifting the geotechnical paradigm towards environmental sciences while accommodating the expanding interests of traditional geotechnical engineers. Further research in assessing the risks associated with EG and development of physical and numerical modelling of geoenvironmental processes, including the integration of EG in the Building Information Modelling (BIM), are the current and latest challenges the education and research institutions are facing. Another challenge is providing a vehicle for the results of the new research to be implemented in practice to supplement the traditional continuous professional development (CPD) seminars and enable wider dissemination across different disciplines.

With the above challenges, among other personal and professional ones you are facing every day, I would like to share the passion for EG with you and also motivate to think outside the traditional boundaries of the mother discipline by never forgetting about the environment we all share.

\section{References:}

Norris, J.E.; Stokes, A.; Mickovski, S.B.; Cammeraat, E.; van Beek, R.; Nicoll, B.C.; Achim, A. (Eds.) 2008. Slope Stability and Erosion Control: Ecotechnological Solutions. Springer, 287pp. 

Assembly Resolution 42/187, 11 December 1987

107 Whitlow, R. 2000. Basic Soil Mechanics. $4^{\text {th }}$ ed. Prentice Hall, 592pp. 